\title{
Comic Strips in Teaching Simple Past Tense for EFL Learners
}

\author{
Habibatul Azizah Al Faruq, Nurhalimah \\ Universitas Muhammadiyah Jember \\ (habibatulazizah@unmuhjember.ac.id)
}

\begin{abstract}
Teaching English needs various media and methods to make the students enthusiastic in teaching and learning process. A lot of media are employed in teaching and learning process. One of media used in teaching grammar especially tenses is comic strips. Comic strips tell a story in form of pictures series and text structures or dialogue. This article aims to find out the effect of using English comic strips as media in teaching simple past tense. A quasi experimental design is used in this study to identify the causal impact of an intervention on target population without random assignment when the treatments were given. The subjects of this study were the seventh grade students of junior high school. The finding of $\mathrm{t}$-test obtained was 3.865 which were higher than $\mathrm{t}$-table 2.08. It means that the comic strips are effective for teaching simple past tense. The comic strips can be used in teaching other aspects such as storytelling, another tense, writing and so forth, and also it can be collaborated with the students' learning style.
\end{abstract}

Keywords: comic strips, simple past tense.

Language is an important tool for communication. People can share their feelings, thoughts, experiences and needs to each other orally or written. Without language, people cannot interact to each other. They cannot communicate their thoughts and ideas or to share information to other people. Language is also an element to ease human's life in communicating what they need to share or inform to others. Having language assists them to transfer anything they have in mind, and it conveys the messages of what one needs to say and transmit. To avoid ambiguity or misunderstanding about the information, people need the language to make the information clear and understood by others. As Crystal (2003) states that English is a global language which means that English is the language which is widely used in the world is English. It makes English has very important roles for the human's life. It is acknowledged to be global language of technology and trade which means that English is as a means of communication.

As the global language, English is crucial to be learnt. We need to master the language to be able to communicate globally. In general, the mastery of English covers language skills such as; listening, speaking, reading, and writing, and language components like; grammar, vocabulary, pronunciation and spelling. Either the skills or the components need to be taught in integrated manner, for these are inseparable elements in learning a language. Sometimes, we find some students who are good at vocabulary, are not able to communicate, since they do not know how to construct good sentences grammatically. 
In expressing ideas students need vocabulary, but without correct grammar it will be hard to say or write the correct sentences.

Grammar is a crucial element of language which should be mastered as it is usually used in writing, speaking, listening, and reading. Grammar consists of rules of constructing sentences that becomes basic knowledge in mastering a language. In this study, the grammar learnt was the simple past tense. The simple past indicates that an activity or situation began and ended at a particular time in the past (Azar, 1993). In school, grammar plays a very important role in mastering language, mainly English. In fact, learning grammar is not fun thing since students have to memorize the complicated structures or formulas of the sentences. This condition makes students not interested in learning grammar. The monotonous way in teaching grammar also makes students having low-motivation in following the teaching learning process. Teachers usually do not provide any media in teaching grammar. Teachers only use textbook in teaching grammar without any media. As a result, it is difficult for students to understand grammar more easily.

A lot of media can be used to teach language, not to mention teaching grammar as one of the components in language learning. Comic strip is one of the media which can be used in teaching grammar. Comic strips, as an inevitable component of visual materials, have been analyzed in terms of their uses as instructional tools as comic books (Williams, 1995).Comic strips tell a story in form of pictures and text structures or dialogue. This statement is similar to Liu (2004: 229) as he states that comic strips can be defined as "a series of pictures inside boxes that tell a story". The use of comic strips for teaching tenses is not complex since a teacher only distributes a piece of comic strips printed on a piece of paper. Then, a teacher asks students to identify the tenses used in the dialogue of comic strips. Comic strips have become one of several interesting ways in teaching tenses since a verb is illustrated in pictures in which the pictures roles as visual examples. Those series of pictures are served in comic strips to help students in with their comprehension on most of the grammar points which taught (McVicker, 2007). Hence, it is good to assist students in learning grammar.

English comic strips have both the strengths and weaknesses. The strengths of it are exciting and motivating, long lasting visual media, entertaining, giving values and moral message, enhancing vocabulary achievement, and a strategy in teaching comprehension (Rokhayani \& Utari: 2014). It implies that with comic strips in learning, students are entertained and motivated for it has interesting and assisting pictures to help them understand and comprehend what the characters in the comics want to convey in their conversation. In addition, it also teaches the students some moral values through the messages of the story. It will help them learn some good wisdom of life which will be good assets to build their soft skills in learning. One crucial impact of it in language learning is that it is able to increase and enhance the students' vocabulary mastery; as a consequence, it helps them with their understanding and comprehension. The sentences presented in throughout the dialogues help the students recognize the structures or grammar of a language. It is good to provide them exposure in the language learnt, especially in the grammar of the language.

Although it has strengths in many ways, it also has weaknesses like it cannot support audio conversation with the native speaker (Rokhayani \& Utari: 2014). Besides, comics also are weakened if there are students who are not visual learners which do not enjoy or able to follow the learning styles with visual media (Rokhayani \& Utari, 2014). It is the duty of the teachers to provide learning which will help them having better understanding and comprehension on the subject being taught. As the role of a teacher is of facilitator in learning 
process, it assures that teachers must find ways to ease their students in their learning. To do so, teachers should use equipped themselves with various teaching strategies, techniques, methods, approaches as well as media to make the lesson more enjoyable for the students during teaching and learning process.

\section{Method}

This study used experimental method which used a factorial $(2 \times 2)$ version of the nonequivalent control group design. It used two classes as the subjects that were given different treatment. The subjects of this study were the seventh grade students of junior high school at MTs. Nurus Sholah Sukowiryo, in Jelbuk, Jember. The subjects were chosen randomly from three classes available in the school. The experimental class was taught by using English comic strips while the other one was not. The data was collected through writing test which was qualitatively analyzed. After taking the data by using pre-test and post-test, they were scored and calculated using SPSS program 16.0 to find out the minimum, maximum, mean, and standard deviation scores. The $t$ test was used for measuring the means score between both groups and determining how substantial is the difference between two means of the groups to find out the significance difference.

\section{Results and Discussion}

This study found that the students who were in experimental group have an improvement of the average score where it was increased from 56.57 to 82.80 .This means that after the students in experimental group getting the treatment of being taught simple past tense using English comic strips, they got significant improvement mean score before and after getting treatment. Whereas in control group, they showed a slight improvement of the average score they got where it was increased from 46.4 to 59.52 . This means that the students in control class got only a slight improvement when they did not get any treatment during research. The students were taught about simple past tense by using traditional teaching that only used the white board as the media without any English comic strips. Teacher has the core attention rather than the students or in other words we can say as more teacher centered learning than student centered.

After calculating the data of experimental and control groups, it then analyzed to find out the effectiveness of English comic strips for teaching past tense. It was started from calculating the mean deviation of each group. For the experimental group, the result was 26.23. Meanwhile for the control group, the result was 13.11 . The calculation was continued to find out the sum of square deviation score for each group. The result of the sum square deviation of experimental group was 717.75 . The control group resulted a lot higher deviation on its sum square, it was 1033.78. The t-test was employed to find out the significant different between groups, experimental and control group. The t-test obtained was 3.865 which were higher than t-table 2.08. It means that the English comic strips are effective for teaching past tense. Therefore, the research hypothesis is accepted. In brief, through this study, it was revealed that the students who were taught simple past tense using comic strips had better achievement than those who were taught by using conventional teaching method. The experimental group students were more outperformed compared to the control group students. It occurred because in the experimental group, the students could express their ideas by seeing the comic strips provided during the learning process. In addition, comic strips can also motivate the students in learning English because it contains a lot of pictures that make them was not bored in the classroom. 


\section{Conclusion}

The finding of this study gives meaningful insight on the implementation of English comic strips in teaching simple past tense. The findings give practical contributions to the English teachers/ lecturers and further researchers. For the teachers/ lecturers it is advised to prepare and consider varieties media in the classroom setting which are appropriate for the level and characteristics of the students. They should consider the students' learning style because each student has different learning; some are visual, audio, and kinesthetic and so forth. Researchers can use the English comic strips in teaching other aspects such as storytelling, other tenses, and other skills in English. The researcher can elaborate the English comic strips with the students' learning style.

\section{References}

Azar, B. S., \& Hagen, S. A. (2009). Understanding and Using English Grammar. White Plains, NY: Pearson Longman.

Crystal, D. (2003). English as a global language (Second Edition). Cambridge, UK: Cambridge University Press. https:// doi.org/https://doi.org/10.1017/ CBO9780511486999.001

Liu, J. (2004). Effects of Comic Strips on L2 Learners' Reading Comprehension. TESOL Quarterly, 38(2), 225-243. https://doi.org/DOI: 10.2307/3588379

McVicker, C. J. (2007). Comic Strips as a Text Structure for Learning to Read. The Reading Teacher, 61(1), 85-88. https:// doi.org/10.1598/RT.61.1.9

Rokhayani, A., \& Utari, A. R. P. (2014). The Use of Comic Strips as an English Teaching Media for Junior High School Students. Language Circle: Journal of Language and Literature, 8(2), 143-149. https:// doi.org/DOI: https://doi.org/10.15294/ lc.v8i2.3018
Williams, N. (1995). The Comic Book as Course Book: Why and How. In The 29th Annual TESOL Convention (pp. 2-27). Long Beach, CA. 